\title{
EUROGRANITES - 45 years and still in progress: Report from the annual 2015 meeting
}

It was the enthusiasm of Professors Jean Didier and Jean Lameyre who, as early as 1971, organised a field trip across the Western French Massif Central granites for students from Orsay and Paris, and other professionals from France. This meeting was followed by trips to Velay, Northern Brittany and Corsica and were called the Granitologists' Annual Excursions. The French initiative spread to other European countries through excursions to granites in Central Spain, Sardinia, Scotland-Northern Ireland and Germany. Through this multinational participation the EUROPEAN NETWORK ON GRANITES was born. After Prof. Tom Andersen coined the name EuRogranites for the field meeting in 1996, an announcement was distributed by Prof. Barrie Clarke's worldwide electronic Granite Network and, since that, these meetings have gained universal popularity. The most recent major development occurred in 2010, when Eurogranites for the first time travelled out of Europe as Prof. Barrie Clarke organized a field trip to Nova Scotia (Canada). Thanks to Prof. Bernard Bonin, who has coordinated these meetings for thirty five years the EUROGRANITES is still very much alive. The history of these annual meetings is presented in Table 1 .

The Eurogranites 2015 field meeting in the Bohemian Massif (Czech Republic) was organized by specialists from the Charles University and Czech Geological Survey in Prague led by Professors Vojtech Janousek and Jiri Zak together with Drs. Kryštof Verner, Jakub Trubac and Jan Franek (Fig.1). The Bohemian Massif (BM), the easternmost and largest inlier of the Variscan belt in Europe, is a type example of a large hot orogen scattered with compositionally diverse plutons. The BM plutonism spanned more than $80 \mathrm{My}$ from the Late Devonian oceanic subduction (375-365 Ma) through the Early Carboniferous microplate collisions (345-335 Ma) to, finally, the Late Carboniferous/Early Permian orogen destruction (310-295 Ma).

The meeting was comprised of five days in the field across the BM tracing the orogen's tectonic development and demonstrating a comprehensive review of the Variscan magmatism.

The scientific program was "kicked off" by short introductory lectures by Jiri Zak: Geological structure of the Bohemian Massif and Vojtech Janousek: The Variscan igneous activity of the Bohemian Massif. The excursion started in the supracrustal Tepla-Barrandian Unit in the centre of the BM consisting of island-arc rhyolites and basaltic products of Neoproterozoic/Early Cambrian age called the Davle Formation allowing discussion of Cadomian active margin processes (Stop 1: Prague-Zbraslav). Next, folded Lower Devonian limestones of the Prague Basin were examined at the type locality "Barrande's Rock Cliff" (Stop 2). Later in the first day, we discussed the oldest Variscan plutonism products (375-373 Ma), the earlyorogenic subduction-related calc-alkaline granodiorites and tonalites (Stop 3: Stenovice).

The second day was devoted to the Central Bohemian Plutonic Complex (CBPC). We discussed the genesis and variability of the ca. 355 Ma old normal calc-alkaline plutons of the so-called Sazava suite, including magma mixing and mingling phenomena and intrusive fabrics overprinted by regional tectonic deformation (Stop 4: Teletín), and ca. 346 Ma old high-K calc-alkaline Blatna suite, associated with syn-magmatic transpressional deformation (Stop 5: Kozarovice, Fig. 2). We observed stoped blocks of the high-K calc alkaline
Table 1

\begin{tabular}{|c|c|}
\hline & Coordinator: Prof. J. DIDIER \\
\hline $1971-$ & Western French Massif Central (J. Didier \& J. Lameyre) \\
\hline $1972-$ & Margeride - Velay (France) (J.P. Couturie \& J. Didier) \\
\hline $1973-$ & $\begin{array}{l}\text { Northern Britanny (France) (J. Didier, M. Le Guen, M. Barrière \& } \\
\text { M. Jonin) }\end{array}$ \\
\hline $1974-$ & Corsica (France) (B. Bonin \& P. Vellutini) \\
\hline $1975-$ & Central Spain (L.G. Corretgé-Castañón \& J.M. Ugidos) \\
\hline & Coordinator: Prof. J. LAMEYRE \\
\hline $1976-$ & Sardinia (Italy) - Corsica (France) (J.B. Orsini) \\
\hline $1977-$ & Scotland - Northern Ireland (P. Bowden, I.G. Meighan and J.A. Kinnaird) \\
\hline 1978 - & $\begin{array}{l}\text { Schwarzwald (Germany) - Vosges (France) (W. Wimmenauer, M. Pagel, } \\
\text { C. Gagny, and P. Fluck) }\end{array}$ \\
\hline $1979-$ & $\begin{array}{l}\text { Margeride - Lozere - Velay (France) (J.P. Couturie, A. Fernandez and J. } \\
\text { Didier) }\end{array}$ \\
\hline $1980-$ & Poitou - Vendee (France) (M. Dhoste) \\
\hline & Coordinator: Prof. B. BONIN \\
\hline $1981-$ & French Alps (G. Vivier, P. Giraud, A. Pecher \& P. Le Fort) \\
\hline $1982-$ & Italian Alps (A. Boriani \& P. Ulmer) \\
\hline $1983-$ & $\begin{array}{l}\text { Northern Ireland - Donegal (Eire) (I.G. Meighan, W.S. Pitcher, M.T. Holder } \\
\& \text { D. Hutton) }\end{array}$ \\
\hline $1984-$ & Marche - Nord Limousin (France) (J.M. Quenardel) \\
\hline $1985-$ & Galicia (Spain) (L.G. Corretgé-Castañón, J. Gil Ibarguchi \& O. Suarez) \\
\hline $1986-$ & Sicily - Calabria (Italy) (A. Rottura et al.) \\
\hline 1987 - & Cornwall (England) (W.S. Pitcher \& M. Stone) \\
\hline $1988-$ & Swiss Alps (S. Ayrton, F. Bussy, I. Mercolli \& F. Persoz) \\
\hline $1989-$ & $\begin{array}{l}\text { Corsica (France) - Sardinia (Italy) (in collaboration of the Société } \\
\text { Géologique de France \& Societa Geologica Italiana) (C. Ghezzo, J.B. Orsini } \\
\text { \& C.A. Ricci) }\end{array}$ \\
\hline $1990-$ & $\begin{array}{l}\text { Catalonia (Spain) (P. Enrique, G. Galan, J. Carreras, H. Duran \& P.R. } \\
\text { Serra) }\end{array}$ \\
\hline $1991-$ & Corsica (France) (B. Bonin \& B. Platevoet) \\
\hline $1992-$ & $\begin{array}{l}\text { Guernsey (Channel Islands) - Tregor (France) (B. Auvray, J. de Bremond } \\
\text { d'Ars \& E. Hallot) }\end{array}$ \\
\hline $1993-$ & $\begin{array}{l}\text { Toledo Mountains - Sierra de Guadarrama (Spain) (C. Villaseca, L. Barbero } \\
\text { et al.) }\end{array}$ \\
\hline $1994-$ & $\begin{array}{l}\text { Southern Bohemia - Hohe Tauern (Austria) (F. Finger, B. Haunschmid \& } \\
\text { A. Schermaier) }\end{array}$ \\
\hline $1995-$ & $\begin{array}{l}\text { Central Bohemia (Czech Republic) (F.V. Holub, V. Janoušek, D. Matejka } \\
\text { \& Š. Táborská) }\end{array}$ \\
\hline $1996-$ & Southern Norway (T. Andersen, J.C. Duchesne, K. Maijer \& R. Verschure) \\
\hline $1997-$ & Scottish Caledonian Granites (E. Stephens, P. Kokelaar and J. Reavy) \\
\hline $1998-$ & $\begin{array}{l}\text { Northern Greece (C. Sideris, A. Katerinopoulos, C. Kyriakopoulos and } \\
\text { A. Magganas) }\end{array}$ \\
\hline $1999-$ & $\begin{array}{l}\text { French Massif Central and Corsica (France), field-trips in connection with } \\
\text { the IV } V^{\text {th }} \text { Hutton Symposium in Clermont-Ferrand (P. Rossi, J.B. Orsini et } \\
\text { al.) }\end{array}$ \\
\hline $2000-$ & Northern Portugal (G. Dias, F. Noronha, N. Ferreira et al.) \\
\hline $2001-$ & Western Carpathians - Slovakia (M. Kohút, I. Petrík, I. Broska et al.) \\
\hline $2002-$ & $\begin{array}{l}\text { Tuscan Magmatic Province (Elba - Italy) (G. Poli, D. Perugini, S. Rocchi, } \\
\text { and A. Dini) }\end{array}$ \\
\hline $2003-$ & $\begin{array}{l}\text { Western Castilla y Leon (Spain) (M. López Plaza, D. Pereira Gómez, M.P. } \\
\text { Moreno et al.) }\end{array}$ \\
\hline $2004-$ & $\begin{array}{l}\text { Galway Connemara \& Leinster granite (Ireland) (J. Reavy, B. Leake, M. } \\
\text { Feely, \& P.S. Kennan) }\end{array}$ \\
\hline $2005-$ & $\begin{array}{l}\text { Proterozoic and Archean granites in Finland (T.O. Rämö, J. Halla, M.I. } \\
\text { Kurhila et al.) }\end{array}$ \\
\hline $2006-$ & $\begin{array}{l}\text { Western Swiss \& French Alps (Switzerland) (F. Bussy, U. Schaltegger et } \\
\text { al.) }\end{array}$ \\
\hline $2007-$ & Granitoids in Poland (Kozlowski, A., Wiszniewska, J., Gaweda, A. et al.) \\
\hline $2008-$ & $\begin{array}{l}\text { Corsica-joint field-meeting IGCP-510 A-type magmatism (B. Bonin, B. } \\
\text { Platevoet et al.) }\end{array}$ \\
\hline $2009-$ & $\begin{array}{l}\text { Arctic Eurogranites Finland \& Russia - Kola Peninsula (J. Halla, E. Heilimo, } \\
\text { V.R. Vetrin, M.I. Kurhila et al.) }\end{array}$ \\
\hline $2010-$ & $\begin{array}{l}\text { Nova Scotia (Canada) (B. Clarke, D.J.W. Piper, G. Pe-Piper, B.J. Murphy } \\
\text { and S.M. Barr) }\end{array}$ \\
\hline $2011-$ & $\begin{array}{l}\text { Magmatism in the uppermost Allochthon (Central Norway) (C. Barnes, A. } \\
\text { Yoshinobu, C. Frost, Ø. Nordgulen et al.) }\end{array}$ \\
\hline $2012-$ & $\begin{array}{l}\text { Granites of the Erzgebirge (Germany) (R.L. Romer, H.J. Förster, U. Kroner, } \\
\text { A. Müller et al.) }\end{array}$ \\
\hline $2013-$ & $\begin{array}{l}\text { The Velay Complex (Eastern French Massif Central) (J.F. Moyen, A. } \\
\text { Villaros and B. Barbarin) }\end{array}$ \\
\hline 2014 - & $\begin{array}{l}\text { Cornubian Batholith - SW England (J. Andersen, R. Shail, B. Simons, } \\
\text { and B. Williamson) }\end{array}$ \\
\hline
\end{tabular}



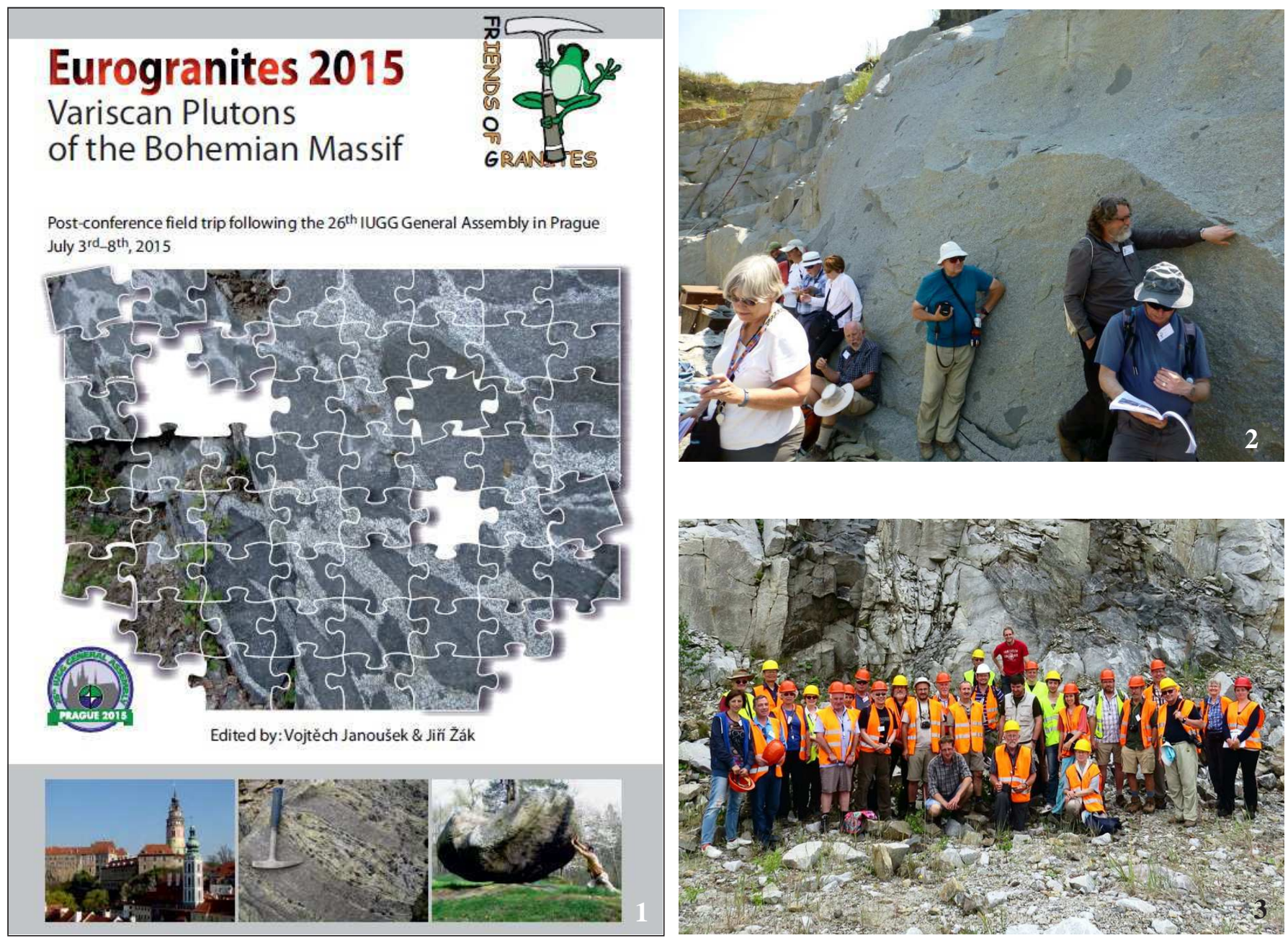

Figures 1-3. (1) Front page of the Eurogranites 2015 Guidebook (Published with permission of the Authors and Czech Geological Survey); graphic design: Vojtech Janousek. (2) Participants in shadow of quarry wall during introduction at Stop 5: Kozarovice, high-K calkalkaline granites of the Blatna suite; photo: Milan Kohút. (3) Conference photo taken in the Rácov quarry (Stop 16); dark subvertical lamprophyre dykes cut the Eisgarn-type granite; photo courtesy of Krystof Verner.

granodiorites mingled with microgranular enclaves in ultrapotassic 'durbachite' pluton (Stop 6: Štedronín) in addition to the ca. $346 \mathrm{Ma}$ normal shear zone along the southern margin of the CBPC separating the Tepla-Barrandian upper crust from the underlying Moldanubian migmatites. Later was discussed the Early Carboniferous orogenic collapse in the BM. In the end of the day, we visited ca. 337 Ma old post-tectonic ultrapotassic two-pyroxene syenitoids of the Tabor Pluton that originated from an enriched mantle source (Stop 7: TáborKlokoty).

The third day topics were granulites in the Variscan orogenic root and their link to ultrapotassic plutons. At the summit of Mt. Klet (Stop 8) in the Blanský les granulite Massif (BLGM) the distribution and nature of HP-HT granulites and petrological variability of the BLGM were explained and the relationships between mafic and felsic granulites, $\mathrm{P}-\mathrm{T}$ conditions of melting of the possible protolith and its early metamorphism, including the role for HP partial melting were discussed (Stop 9: Kokotín). The Plesovice quarry (Stop 10) exhibited a complex structural record (compositional banding, mylonitic foliation, folding and/or shearing) of the Grt $\pm \mathrm{Ky}$ granulites and ultrabasic bodies. Locality is famous for large prismatic zircon crystals used as natural reference material for $\mathrm{U}-\mathrm{Pb}$ and $\mathrm{Hf}$ isotopic microanalysis. The last stop of the day (No.11: Skalka) documented coincidence of macroscopic structural and magnetic (AMS) emplacement fabrics of the Knizecí Stolec durbachite pluton, and relationships of durbachites to the host granulitic rocks.

The fourth day focussed on the Moldanubian Batholith (MB) one of the largest plutonic bodies in the entire Variscan belt. We studied the variability of plutonic rocks in the Moldanubian area from the oldest rocks discovered in Bohemia - tonalitic orthogneisses with Eburnean (ca. 2.1 Ga) protolith age (Stop 12: Rajov) - to various (coarse-grained porphyric I- to I/S-type, medium-grained S-type, finegrained I/S-type, and pegmatite and aplite dykes) Carboniferous granitoids. The MB dominantly consists of post-collisional granitic rocks such as I-type, ca. 331-323 Ma old, porphyritic Weinsberg granite with abundant xenoliths and K-feldspar phenocryst accumulations (Stop 13: Sokolci) and the S-type, ca. 330-327 Ma old, medium-grained two-mica Eisgarn type granites with countryrock xenoliths and associated migmatites (Stop 14: Mrakotin).

The theme of the last day was the late-orogenic low-P high-T crustal anatexis and S-type plutons in the orogen's interior with the post-collisional Pelhøimov core complex, a large-scale granitemigmatite dome in the Moldanubian Zone, showing transition from 
ca. 329 Ma migmatites (metatexites and diatexites) to S-type granites (Stop 15: Vanov). Later, we discussed intrusive relations of the Eisgarn type granite, magmatic stoping of ca. 329 Ma migmatized paragneiss (roof pendant) in ca. 327 Ma old granite, post-emplacement magmatic deformation, and rapid exhumation of the granite-migmatite complex to upper crustal levels (Stop 16: Rácov, Fig. 3). Lastly, we debated the field structural and magnetic (AMS) kinematic indications for sequential emplacement of the nested granite diapir-Melechov Pluton (Stop 17: Dolni Mesto).

Each day of the trip offered beautiful landscapes, historic tourist attractions (Praha - Prague, Ceske Budejovice - Budweis, Cesky Krumlov, and Telc included to the list of UNESCO World Cultural Heritage Monuments), as well as great Czech beer and cuisine in the evenings. The Eurogranites 2015 meeting was attended by 26 participants (9 - USA, 4 - UK, 4 - Russia, 3 - France, 2 - Germany,
1 - Belgium, 1 - Ireland, 1 - Poland, 1 - Slovakia) and 5 local organizers.

The next Eurogranites 2016 meeting will be held in Serbia under guidance of Prof. Vladica Cvetkovic from the University of Belgrade.

\section{Dr. Milan Kohút}

Senior Research Scientist

Department of Basement Geology

Dionýz Stúr State Institute of Geology

Mlynska dolina 1

81704 Bratislava

Slovakia

E-mail:milan.kohut@savba.sk milan626@gmail.com

\section{Episodes is your window to the world. Subscribe today!}

\section{Episodes}

Name (please print)

Address

City State/Province

Country Zip/Postal Code

Please begin my subscription from the year

To start your subscription, fill this form and mail to:

\section{Episodes}

Geological Society of India

No.63, 12th Cross, Basappa Layout

Gavipuram P.O.,

Bangalore - 560 019, INDIA

Telefax: +91-080-26613352; Phone:+91-080-22422943

Email: episodes.journal@gmail.com
Payment may be made by:

- Checks/Bank draft (US \$ only) payable to: 'Geological Society of India A/C Episodes'

- Bank Transfer:

'Geological Society of India A/C Episodes'

Bank Name : Canara Bank, Hanumanthanagar Branch Bangalore - 560019

S.B. A/C No. : 0472101044517

Bank Code : 560015020

Swift Code : CNRBINBBLFD

IFSC : CNRB0000472

Annual Subscription rate: US $\$ 30$ 